Simplon are: (a) The Jura-Trias sediments, lithologically often much alike and much interfolded; $(b)$ the Paleozoic crystalline schists; and $(c)$ the gneiss of Monte Leone and the Antigorio gneiss, both stated to be of Archæan age. These rocks throughout contain radium, and for the most part in quantities much above what hitherto has been ascribed to sedimentary or igneous rocks.

Some thirty-six typical samples, taken from various points in the tunnel, have been examined. The poorest in radium are certain anhydrite rocks. Certain amphibolite schists go very high. The Antigorio gneiss rises from $10.5 \times 10^{-12}$ and $8.0 \times 10^{-12}$ grams radium per gram of rock at the Italian entrance to $23.7 \times 10^{-12}$ at 4,000 meters inwards. Some of the Archæan gneisses yielded very high results.

Such quantities of radium if generally distributed throughout the rocks of the massif would be sufficient to disturb any forecast of the temperature which under normal conditions would be encountered at the level of the tunnel. It is suggested that the radium was in fact the source of the discrepancy between the predicted and the observed rock temperatures.

As it is improbable that these results are unique and apply only to this particular sedimentary accumulation and locality, they appear to point to hitherto unsuspected quantities of radium \(and its parent elements) in the immediate surface materials of the earth. It seems impossible to avoid the conclusion that these elements were precipitated along with the sediments entering into the composition of the massif. The question then arises whether the accumulation of such quantities or radioactive elements may not enter as a factor in the events attending mountain-building. It can be shown that an area of sedimentation whereon has been accumulated some 10,000 meters of sediments, having a richness in radium comparable with the Simplon rocks, must necessarily become an area of greatly lessened crust-rigidity, and would hence become the probable site of crust-flexure under tangential compressive stress.

Further investigation will be required be- fore such views can be generalized and the importance of radium as a source of instability of the earth's crust be determined. Apart from any speculations as to the influence of radium as the cause of an energetic substratum, the shifting of radium and its parent elements by denudation must be regarded as a convection of thermal energy, and this convection, if the quantities involved are sufficient, must, under the conditions referred to above and the unceasing action of denudation, become rhythmic in operation, and at the same time must result in shifting the areas of high temperature and crust-weakness from age to age as the site of sedimentary accumulation changes.

J. JoLY

\section{THE ARC OF PERU}

The Committee of the French Academy of Sciences having scientific control of the French. Geodetic operations on the equator has reported the completion of the remeasurement of the historic arc of Peru. ${ }^{1}$

This arc was measured by the French (1736-1743) and used in connection with a similar arc in the Arctic regions, also measured by the French, to decide a question in regard to the form of the earth which had arisen as the result of Cassini's surveys in France.

A discussion of the measurement of the arc can be found in the report of the Superintendent of the Coast and Geodetic Survey for 1889, appendix 7 .

In 1889 , the question of remeasuring this arc was brought before the International Geodetic Association by the Delegate of the United States, Professor George Davidson, who suggested that France should have the prior right to execute the work.

Circumstances prevented any active work until 1898, when the discussion of the subject was renewed in the same association as the result of a motion offered by the Delegate of the United States, Mr. E. D. Preston. The association voted in favor of the proposition to remeasure the are and the French delegates undertook to have the work done.

${ }^{1}$ Comptes Rendus Hebdomadaires des Séances de L'Académie des Sciences, No. 6, 5 Août, 1907. 
Officers of the Geographic Service of the French Army left Paris for Ecuador in May, 1899, and the work was continued until completed.

The arc extends from Tulcan, Ecuador, Lat. $+0^{\circ} 48^{\prime} 25^{\prime \prime} .6$ to Payta, Peru, Lat. - 5 ${ }^{\circ}$ $05^{\prime} \quad 08^{\prime \prime} .6$ and the work accomplished in the remeasurement may be summarized as follows; viz. :

Seventy-four geodetic stations.

Three base lines measured.

Eight differences of longitude determined between stations at Tulcan, Piular, Quito, Latacunga, Riobamba, Cuenca, Machala, and Payta. The first five of these stations are distributed along the northern section of the arc, the sixth at the middle of the southern section, the seventh on the coast at the same latitude as the sixth, and the last at the end of the southern section, on the coast.

The comparison of the differences of longitude, geodetic and astronomic, between the stations at Machala and Payta and the station at Cuenca will throw light on the form of the geoid, as the first two stations are on the coast and the third is in the inter-andine region.

Six azimuths determined: at Tulcan, Piular, Quito, Riobamba, Cuenca, and Payta.

Sixty-four determinations of latitude.

Forty-eight magnetic stations: distributed all along the arc.

Six pendulum stations. One of these is at Machala, on the coast, at the point where observations for longitude were made; one at the foot of the western Cordillera, near Chimborazo; one, at an elevation of 4,150 meters in the western Cordillera; two, in the interandine region at Riobamba and Quito; and one at an altitude of 1,800 meters in the plain of the Amazon on the eastern slope of the eastern Cordillera.

Two lines of levels of precision: one from the Riobamba base line to Guayaquil and to the tide gauge at Salinas on the Pacific Coast and the other from the southern base line to the tide gauge at Payta, the two lines covering a distance of 410 kilometers.

A study was made of the natural history of the country and important collections were made, which will add to the knowledge of botany, zoology, anthropology and ethnology.

The preliminary computations are far enough advanced to assure the value of the observations. The closure of the triangles and the agreement of the computed and the measured lengths of the base lines compare well with the results obtained in the revision of the meridian of France.

The publication of the results of the work will be regarded as an important event by geodesists throughout the world.

The work reflects great credit on the French government for its liberality in providing the necessary funds, upon the French savants who directed the work and upon the gallant officers who made the scientific observations under most trying and unusual conditions.

\section{IsAaC WINSTON}

\section{REPORT OF THE INTERNATIONAL COMMIS-} SION ON ZOOLOGICAL NOMENCLATURE ${ }^{1}$

THE International Commission on Zoological Nomenclature has the honor to submit the following report to the Seventh International Zoological Congress:

The Sixth International Congress referred to the Commission for consideration and report a paper (presented to that congress) urging that "absolute priority" be adopted in the law of priority, instead of taking 1758 as a starting point for zoological nomenclature.

While appreciating the sentiments which gave rise to the proposition in question, your commission is unanimously of the opinion that both practical and theoretical considerations contravene the adoption of "absolute priority" in preference to the date 1758 . Accordingly, it is herewith recommended that article 26 of the code be not changed in respect to the point at issue.

During the past three years; several zoologists have submitted to the commission propo-

${ }^{1}$ Presented to the Seventh International Zoological Congress, Boston, Mass., August 19-23, 1907, and unanimously adopted after two public readings. 